glands, including typhoid fever, buhonic plague, parotitis, mastitis, adenitis, etc.; (e) of the lungs, including pulmonnry tuberculosis, croupous pneumonin, etc.

It is evident that under several of the suhdivisions the diseases mentioned would require a subherding to designate definitely the nature of the infectious process. Thus we would have, for example, to specify whether a peritonitis was tubercular or due to streptococcus-infection or to some other known micro-orgnnism; an adenitis might be due to syphilitic or tubercular infection or to one of the pus-cocci ; $n$ conjunctivitis to gonococcus-infection or to some other pathogenic microorganism, etc.

It will be noted that, both in our clnssifiention hased upon the nnture of the infectious agent and in that based upon the special tissues or organs involved in the infectious process, we have not included the eruptive fevers. It is hardly necessary to say that this omission is due to the fact that we hnve as yet, no positive knowledge to guide us in placing these infectious diserses in the systems of classification suggested, which are, therefore, necessarily incomplete.

\title{
AN OPERATION FOR VALVULAR STRICTURE OF THE URETER.
}

\section{By Cenistiax Fenozb, M.D., or culcaco.}

Ir cases of hydronephrosis or pyelitis with distention (pyonephrosis) it is not uncommon to find comparatively nnrrow or thin-walled, semilunar valves located transversely in the ureter. These open upward and have the same mechanical nction as the valves in veins, and stop the passage of liquid through the ureter on its way from the kidney to the bladder. These valves are sometimes single and sometimes multiple, two or three in the same ureter. They have been depicted in Rayer's atlas, ${ }^{\prime}$ and are not uncommonly mentioned in the descriptions of specimens in the literature. They cause a gradually increasing impediment to the flow of urine, and effect dilatation of the ureter above and usually near to the valve, so that a ureter with multiple valves will present as many dilatations and constrictions as there are valves. It is natural that if small stones form in the kidney, they should be arrested at the vnlves.

That such a valve can he successfully operated upon from within the ureter through a longitudinal incision in the lntter is well illustrated in the following case : :

I Rager : Traite des Jraladies des Re!nz, Paris, 1837. 
CAsE. Synopis: in 1880, at the age of seventeen years, probably traumatic right floaling kidney; remittent atlacks of pain, reatwakened after first pregnancy, in 1885, to disappear for eight years, returning in 1893, subsequent to miscarriage, to become internitient or almostom ingust 6,1805 removal of four stones from vireter above a valvular striclure; longit dinal ureterotomy over stricture; excision of stricture; plastic operation on ureter; wound in pelvis left open for bougie passed down into ureter; wound healed withont fistula in six weels; patient well in March, 1896. sevea montha later.-Mirs. G., aged thirty-two years, was referred to me hy the courtesy of Dr. E. E. Simpsoa, aad eatered the German Hospital, ia my service, August 1,1895 . The patient's family history was good. She had had the ordinary diseases of childhood, hut was ia other respects ia excellent health uatil her seveatceath year. At this time, after jumping from a wagoa to the grouad, she at once experieaced pain in the right side immediately uader the rihs, so severe that she faiated. She was not coafiaed to her hed, and the pain was not coastant, hut after an intermissioa of several days intense paia, lasting from a few hours to several weeks, would recur. The pain was located in the right hypochoadriac regioa. No hlood was noticed ia the uriae or stools either immediately following the injury or subsequently.

Ienstruation commenced at the age of eighteea years, and she was fairly regular and had comparatively little pain or discomfort. She married at tweaty-one years; has two childrea. After the hirth of the first child the paia in the side again became quite serere, hut during her second preganncy she complained of little pain. The second child was born three years after the hirth of the first, after a tedious lahor. Oa the third or fourth day she had a chill, followed hy fever, and during the six weeks following had fever and intense pain ia the hack, the left half of the ahdomen, and the joints in various parts of the body. During the first week after her confinement a large slough, four inches in length, extending from the anus upward over the sacrum, occurred. Fire weeks later the gangrenous tissue was removed, hut the wound did not heal for three moaths and a half. Duriag the next four years the patieat had three miscarriages. At the time of the last miscarriage, ia 1893 , the patient had the same pain that she had had fifteen years previously ia the right hypochoadriac region, ranging to the median line.

The patient was somewhat emaciated; heart and lungs a ormal ; abdominal examiaation revealed an ohscurely defined tumor in the right side of the ahdomeu, close to the umhilicus, four inches loag hy three iaches wide, dull upon percussion. The tumor was readily movable to the medias line and hackward to the normal positioa of the kidney, hut attempts to move the tumor caused considerable pain. Vaginal examia ation showed that the uterus was somewhat ealarged, hut ia aormal position, and not freely movahle. Pressure over the ovaries caused oaly slight paia. The uriae contained neither alhumin aor sugar.

During the attacks of pain she urinates frequently, hut passes oaly small quantities of urine. The pain alvays hegins ia the right lumhar regioa, and from here radiates to the epigastrium, anterior part of chest, right and left iaguinal regions, and also sometimes iato the leg. She has lost forty pouads in weight duriag the last seven years.

Diagnosis. Cystoaephrosis of right movahle kidney, prohahly due to stoae in kidney or pelvis. Prohably infected. 
I therefore advised exploratory incision for drainage and possible removal of stones.

Operation. On August 6th I operated in the following manner: the patient was ansesthetized with ether and placed on the left side on a cushion. An incision was made hetween the trrelfth rih and the rim of the pelvis forward for about nine inclies from the border of the erector spinx muscle. (Fig. 1.)

Fic.1.

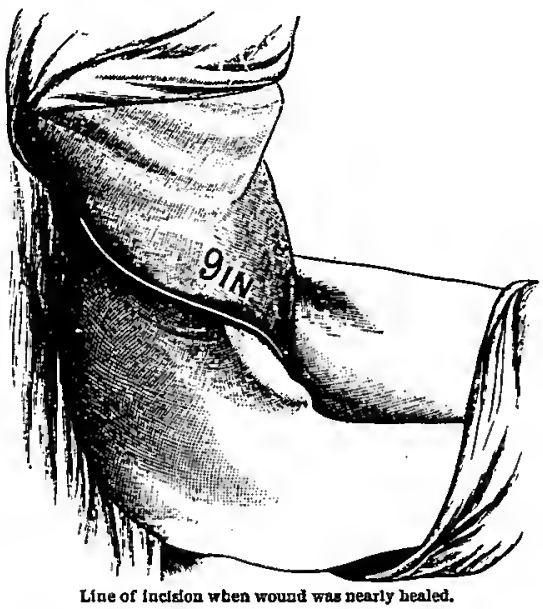

The kidney was large with but little perirenal fat, and was freely movahle. Two small cysts presented on the convex surface of the kidney, ahout the size of a pes, which contained clear fluid. A part of the kidney-tissue which included these cysts was removed for examination. After isolation of the pelvis, which I found to he somewhat dilated, but in which I could feel no stones, I laid bare the ureter and felt a nodular mass two inches below the pelvis. I then incised the pelvis longitudinally and ahout an ounce of urine escaped, from which cultures were made. I could now insert my little finger down into the dilated ureter for an inch without feeling a stone, but upon manipulstion of the ureter with the other hand I was ahle to squeeze four stones up into the pelvis and remove them through the wound in the pelvis. (Fig. 2.) A gound passed down fiom the pelvis into the ureter was arrested two and $\mathbf{a}$ half inches helow the pelvis, at a point where $\mathbf{a}$ somewhat soft thickening was felt on palpation. A longitudinal incision was now made three-eighths of an inch long intu the ureter upon the ead of the sound 
nhorc, through and below a transverse valvular stricture. A prabe in. serted through the opening in the ureter bel ow the stricture passed easily down into the hladder. By holding the longitudinal round open and stretching this part of the urcter over the index-finger I elipped off the valvular stricture ( $\mathrm{Fig}$. 3) from vithin the ureter with Ecissors, leaving the muscular and ioternal coats of the ureter intact. I now made my plastic operation oo the ureter' and inserted a flexible bougie, No.12, from the wound in the pelvis into the uretcr. The wound in the pelvis was left open. Upon digital exploration of tlic calices through the round in the pelvis I found the calices moderately dilated, and in one of them

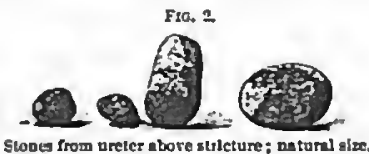

a emall stone, which I reuoved. No other stones were found after careful examinatiou. On this account I did not consider it necessary to ineise the kidncy on its convex surface. Rubber dminage-tubes were then inserted, one down to the wouud in the ureter, and another to the pelris of the kidncy. These tuhes were surrounded with gauze. The external wound was closed with heary silk sutures.

- The operation oceupied trso hours." At the close of the operation the paticnt was in good condition, pulse strong, respiration good. She vom. ited trice after the operation. In the evening she was catheterized and two ounees of dark-brown urioe withdrawn. She complained of severe pain in the wound. During the night sbe pased four ounces of urine and toward morning the pain decrensed.

F). 3.

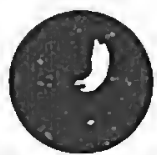

Cireular ralre in the areler ; nituril atize.

Mieroscopical examination of the valve (Fig. 4) sliowed that this consisted of firm fibrillary conncctive tissuc, with normal distribution of ressels (a), no muscular fibres of the wall extending into it. The free border of the valre looking into the lumen of the ureter $(d)$ was clad with stratified crlindrical and cuhoid epitbelium $(b)$. The border of the valve was folded, and thus a eross-section througb the bottom of a foll shorsed an islnnd of cuboid epithelial cells (c).

Tth. The patient vomited sereral times, complnined of severe pain in the afternoon, and passed hloody urinc. Dnring the twenty-four hours she passed sixteeu and a half ounces of urine. She complained of serere

1. Fenger: Joumal of the American Medical Assoclatlon, Sarch 10, 1894. 
pain in the wound, but was otherwise bright and cheerful. Considerahle discharge found in the dressings.

8th. The patient passed bloody urine throughout the day and complained of very severe pain.

$9 t h$. The patient had hut little pain during the day, and the nausea and vomiting ceased.

10th. The gauze was almost dry, indicating that the urine had passed along the bougie through the nreter.

11th. The patient was penspiring profusely for ahout half an hour in the evening, nnd a little later complained of severe pain.

FTa. 1.

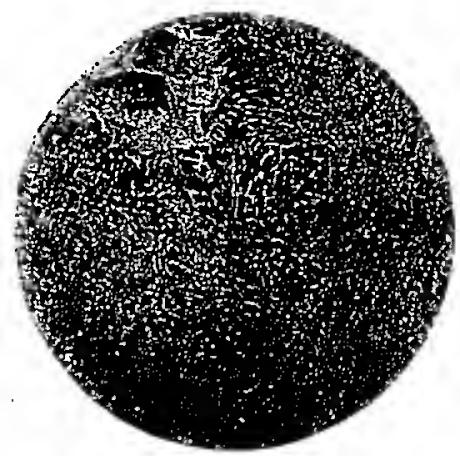

Hricrosople sectlos of valve.

12th. Thirty ouce of urine were passed in the twenty-four hours.

$13 t h$. The patient complains of severe pain. The bougie was removed, but the drainage-tube nllowed to remain in place. In the afternoon she complained of severe pain.

$15 t h$. The patient complains of sharp pain in the bladder nt the close of urination and also of pain in the wound.

20th. Condition of wound and patient excellent.

26th. No urine in the dressings. Drainage-tube to the pelvis of the kidney removed and tube to the wound in ureter shortened.

September 18t. Drainage-tube removed.

$8 t h$. The patient sitting up. Feels strong, and is hright and cheerful. 20th. The patient left the hospital for her home. The wound was healed with the exception of a narrow superficial granulating line.

On March 19, 1896, Dr. Simpson wrote me as follows : "Mrs. G. is doing remarkahly well."

It will he seen that the operation for infected cystonephrosis in this case was not nephrotomy, as the convex surface of the kidney was not divided at all. Pelviotomy (opening of the pelvis) was made, partly for 
the removal of the stones equeezed up out of the ureter and partly for the exploration of the ureter and calices.

Exploration of the ureter with the sound led to the detection of the stricture, a valve, which was excised through a longitudinal opening in the ureter at its seat. I consider this operation preferahle to excision of the entire rall of the ureter and invagination after Van Hook's method, as it is followed hy the least possihle shortening of the canal. This point may he of importance if more than valvular stricture should have to he operated upon.

Exploration of the calices can he made just as well through an incision in a somewhat dilated pelvis when the latter is wide enough to permit exploration with the finger and sound. For additional security against leaving stones in hidden calices with narrow entrances it would be well to explore through the convex surface of the kidney with steel needles. When this is done in addition to digital exploration throngh the pelviotomy-rround $I$ think there is as little risk of overlooking stones as exists whea the convex surface of the kidaey is divided. To avoid dividing the posterior surface of the kidney nvoids hemorrhage, the operation on the pelvis of the kidney heing entirely hloodless.

For the local treatmeat of pyelitis-that is, inflammation of the pelvis and calice-drainage through the wound in the pelvis will he sufficient, at least in ordinary crses of stones and valves in which, hy removal of the cause, we may reasonahly expect the pyelitis to come to an end.

209 LA SALLE AVEXUE

A CASE OF SYRINGOMYYLIA LIMITED TO ONE POSTERIOR HORN IN THE CERVICAL REGION, WITH ARTHROPATHY OF THE SHOULDER-JONNT AND ASCENDLNG DEGENERATION IN THE PYRAMIDAL TRACTS.'

BY F. X. Dercum, M.D.,

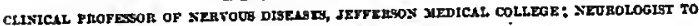
THE PHILAOELPHLA GORPTTAL;

AND

W. G. SPILLER, M.D.,

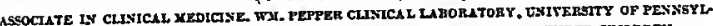

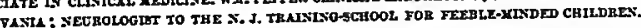

If one glances at the extensive literature oa syringomyelia, as given in Schlesinger's recent monograph, he feels as though he must offer an apology for adding auother case. Syringomyelia with arthropathy followed hy autopsy and an examination of the spinal ganglia; ascending. degeneration in the direct nnd crossed pyramidal tracts nhove the focus 
of destruction in the cord; gliosis extending from the second cervical segment to the extreme end of the conus terminalis; destruction of one posterior born alone, from the second cervical to the first dorsal eegment, with diminution of the Interal column on the same side; pachymeningitis involving a large portion of the dorsal region-these are conditions which seem to justify us in presenting the following case for your consideration :

C. H., male, aged forty-five years, $\mathbf{n}$ native of Sweden, unmarried, and n lahorer hy occupatiou, was n lmitted to the nervous wards of the Philadelpbia Hospital Jnnuary 9,1883. His family history did not appear to be especially significant. His father had died of phthisis, his mother of old age. Two brothers were living and in good health. His personal history previous to the present nffection nleo failed to present factors of importance. He had had typhoid fever when twenty yenrs of age, hut no other illness of moment. Venereal history was denied, and he had always been tempernte in his hahits.

About three years before admission, while working in a sanmill, he did some henvy lifting and strained his back. He was ohliged to go to bed for a day, but afterward felt no evil effects. About three years later he began to suffer from pains in the legs and a band-like pain about the lower part of the chest. These pains gradually grew worse, and soon his walking was interfered with. He noticed that his legs were getting weak, and that be could not walk as well as formerly. His feet would drag slightly and the toes would occrsionally catch upon the ground and cause bin to fall. He noticed also occasional cramp-like pains in the calves of his legs. Gradually loss of power became more and more marked, and when admitted to the hospital he was unable to walk, but could sit up in $\mathrm{n}$ chair.

The legs presented the symptoms of spastic paraplegia, and later on marked contractures made their appenrance. Gradually loss of power became complete, and be lay in hed for the last four or five years with both legs drawn upward toward the trunk, especially tbe rigbt, the thighs heing flexed more or less upon the abdumen and the legs flexed upon the thighs. He could not move the legs in the least, and rigidity was so grent that it was impossihle to extend them even passively. The knee-jerks were botb markedly exaggerated. On the right side, however, the reaction gradually disappeared, owing to the fixed position of the limh. Ankle-clonus was also present, hut was finally lost, likewise due to the fixation produced hy the contracture. General muscular wasting also took place in hoth thighs and legs.

Early in the case the bowels were constipated, and he had also difficulty in voiding urine. Little by little paralysis of retention set in, and finally hoth howels and bladder were emptied without the patient's knowledge.

Cutaneous sensihility was early lost in the legs; but the nature of the affection was not suspected until 1890, when n detriled examination revealed not only that the cutaneons sensihility was nhsolutely lost in both legs, hut that this Ioss extended nlso upward upon the trunk ante-

1 See also clinleal lecture dellvered at the PbDadelphis Elospital, 1600. by one of the writers. International clinles, second serles, rol. 4. p. 106. 